\title{
INCIDENCE OF CONGENITAL ABNORMALITIES IN LIVERPOOL, 1960-64
}

\author{
BY
}

\author{
R. W. SMITHELLS, M.B., M.R.C.P., M.R.C.P.Ed., D.C.H. \\ Consultant Paediatrician and Medical Superintendent, \\ Alder Hey and Olive Mount Children's Hospital, Liverpool
}

A register of infants with congenital defects born to mothers resident in Liverpool and Bootle has been maintained in the Department of Child Health, University of Liverpool, since January 1,1960 . The aim is to record all infants, live and stillborn, with any congenital defect. Primary notifications are made to the registry soon after the birth of defective infants. Several supplementary sources of information are available. Final ascertainment is at school entry medical examination (at age 5 to 6 years) in survivors, and at necropsy (unless refused) in those stillborn or dying in early life. Details of the methods of ascertainment and registration have been published elsewhere (Smithells, 1962).

TABLE I

INCIDENCE OF CONGENITAL ABNORMALITIES, LIVERPOOL, 1960-64

\begin{tabular}{|c|c|c|c|c|c|}
\hline \multicolumn{3}{|l|}{ Malformation } & $\begin{array}{l}\text { Number } \\
\text { ascertained }\end{array}$ & $\begin{array}{l}\text { Incidence } \\
\text { per } 1,000 \\
\text { total births }\end{array}$ & Notes \\
\hline $\begin{array}{l}\text { Anencephaly ... } \\
\text { Spina bifida and cranium bifidum } \\
\text { Hydrocephalus without spina bifid } \\
\text { Other central nervous system defec }\end{array}$ & & $\begin{array}{l}\ldots \\
\cdots \\
\cdots \\
\end{array}$ & $\begin{array}{r}286 \\
306 \\
50 \\
3\end{array}$ & $\begin{array}{l}3 \cdot 14 \\
3 \cdot 36 \\
0 \cdot 55 \\
-\end{array}$ & $\begin{array}{l}\text { Includes iniencephaly } \\
\text { Excludes anencephaly and spina bifida occulta }\end{array}$ \\
\hline \multicolumn{3}{|c|}{ Total infants with C.N.S. malformations . } & 645 & $7 \cdot 07$ & $\begin{array}{l}\text { In addition } 42 \text { anencephalics were notified as having spina } \\
\text { bifida and } 129 \text { cases of spina bifida as having hydrocephalus }\end{array}$ \\
\hline Congenital heart disease $\quad .$. & . & . & 459 & $5 \cdot 03$ & $\begin{array}{l}\text { Excludes } 87 \text { infants notified as having heart murmurs but } \\
\text { subsequently found to be normal }\end{array}$ \\
\hline Mongolism (Down's syndrome) & . & .. & 130 & 1.43 & \\
\hline $\begin{array}{l}\text { Cleft palate without cleft lip } \\
\text { Cleft lip and palate } \ldots \\
\text { Cleft lip without cleft palate }\end{array}$ & $\begin{array}{l}\cdots \\
\cdots\end{array}$ & $\begin{array}{l}\ldots \\
\cdots\end{array}$ & $\begin{array}{l}45 \\
57 \\
38\end{array}$ & $\left.\begin{array}{l}0.49 \\
0.63 \\
0.42\end{array}\right\}$ & Cleft lip with or without cleft palate: 1.05 per 1,000 \\
\hline Total infants with clefts $\ldots$ & .. & . & 140 & $1 \cdot 54$ & \\
\hline $\begin{array}{lll}\text { Hypospadias .. } & \text {.. } & \text {.. }\end{array}$ & . & .. & 112 & $1 \cdot 23$ & Probably under-reported \\
\hline $\begin{array}{l}\text { Defects of kidneys and ureters } \\
\text { Defects of bladder } \ldots \\
\text { Genital tract defects }\end{array}$ & $\begin{array}{l}\cdots \\
\cdots\end{array}$ & $\begin{array}{l}\ldots \\
\cdots\end{array}$ & $\begin{array}{l}86 \\
15 \\
26\end{array}$ & $\begin{array}{l}0.94 \\
0.16 \\
0.28\end{array}$ & \\
\hline Total genito-urinary defects & . & .. & 239 & $2 \cdot 62$ & \\
\hline $\begin{array}{l}\text { Syndactyly and polydactyly.. } \\
\text { Talipes } \\
\text { Congenital "dislocation" of hips } \\
\text { Other skeletal defects }\end{array}$ & $\begin{array}{l}\cdots \\
\therefore \\
\cdots\end{array}$ & $\begin{array}{l}\cdots \\
\cdots \\
\cdots\end{array}$ & $\begin{array}{r}125 \\
242 \\
61 \\
189\end{array}$ & $\begin{array}{l}1 \cdot 37 \\
2 \cdot 65 \\
0.67 \\
2 \cdot 07\end{array}$ & $\begin{array}{l}\text { Excludes infants with spina bifida; figure probably unreliable } \\
\text { Unreliable }\end{array}$ \\
\hline Total skeletal defects & . & .. & 617 & $6 \cdot 77$ & \\
\hline $\begin{array}{l}\text { Intestinal obstructions } \\
\text { Exomphalos .. .. } \\
\text { Defects of liver, pancreas and bili }\end{array}$ & $\begin{array}{l}\cdots \\
\text { iary tr }\end{array}$ & & $\begin{array}{r}114 \\
33 \\
13\end{array}$ & $\begin{array}{l}1 \cdot 25 \\
0 \cdot 36 \\
0 \cdot 14\end{array}$ & $\begin{array}{l}\text { Includes oesophageal atresia and Hirschsprung's disease; } \\
\text { excludes exomphalos, annular pancreas and mucoviscidosis } \\
\text { Excludes mucoviscidosis }\end{array}$ \\
\hline Total alimentary defects & . & . & 150 & $1 \cdot 65$ & \\
\hline $\begin{array}{l}\text { Defects of ears and related parts } \\
\text { Defects of jaw, tongue and pharyn } \\
\text { Defects of larynx, trachea, lungs } \\
\text { diaphragm ... } \quad . . \\
\text { Defects of eyes } \quad . .\end{array}$ & $\begin{array}{l}\ddot{1 x} \\
\text { and } \\
\cdots \\
\cdots\end{array}$ & $\begin{array}{l}\cdots \\
\cdots \\
\cdots\end{array}$ & $\begin{array}{r}106 \\
54 \\
55 \\
24\end{array}$ & $\begin{array}{l}1 \cdot 16 \\
0 \cdot 59 \\
0 \cdot 60 \\
0 \cdot 26\end{array}$ & $\begin{array}{l}\text { Includes pre-auricular skin tags, branchial cysts, and fistulae } \\
\text { Includes micro- and retro-gnathia } \\
\text { Includes diaphragmatic hernia } \\
\text { Figure probably unreliable }\end{array}$ \\
\hline Total Defective Infants & $\ldots$ & $\ldots$ & 2,182 & $23 \cdot 9$ & \\
\hline
\end{tabular}


This report summarizes the findings in the first 5 years of the study, which continues. Only children born in the first 2 years of this period (1960-61) have reached school age, but experience has shown that the number of previously undetected defects found at school entry is very small and does not significantly affect incidence figures.

The survey covers both hospital and home deliveries and is therefore a true population study. The total number of births in the survey area in 1960 to 1964 inclusive was 91,176 . The incidence of the main defects and groups of defects is shown in Table I.

\section{Discussion}

There is no satisfactory or agreed definition of a congenital defect and comparisons of total incidence reported from different centres are therefore of limited value. The figures here reported do not include undescended testicles, hydroceles, hernias (other than diaphragmatic), birth marks, mental defect, or defective vision or hearing. Comparative incidence of individual defects are of more value provided that clear definitions are given (e.g. whether spinal cord defects include those with associated anencephaly).

The only published British study comparable in size and method to the Liverpool series is that of McKeown and Record (1960) from Birmingham; their figures for 56,760 births in 1950 to 1952 with a 5-year follow-up are compared with the Liverpool figures in Table II.

There is a remarkable similarity between the Liverpool and Birmingham figures for the incidence of malformed infants. So far as individual lesions are concerned, the only striking difference is in anencephaly and spina bifida, both of which are appreciably more common in Liverpool. The periods covered by the two surveys are not identical, but the incidence of anencephaly and spina bifida in Birmingham was rather lower in 1960-64 than in 1950-54 (Leck, 1966).
TABLE II

INCIDENCE OF CERTAIN CONGENITAL DEFECTS PER 1,000 TOTAL BIRTHS, WITH 5 TO 6 YEAR FOLLOW-UP

\begin{tabular}{|c|c|c|c|c|}
\hline \multicolumn{3}{|l|}{ Defect } & $\begin{array}{c}\text { Liverpool, } \\
1960-64 \\
\text { (91.176 births) }\end{array}$ & $\begin{array}{c}\text { Birmingham, } \\
1950-52 \\
\text { (56 } 760 \text { births) }\end{array}$ \\
\hline $\begin{array}{l}\text { Anencephalus } \\
\text { Spina bifida (without } \\
\text { anencephalus) } \\
\text { Hydrocephalus (without } \\
\text { spina bifida, etc.) } \\
\text { Mongolism } \\
\text { Congenital heart disease } \\
\text { Cleft lip ( } \pm \text { cleft palate) } \\
\text { Cleft lip and/or palate }\end{array}$ & $\begin{array}{l}\cdots \\
\cdots \\
\cdots \\
\cdots \\
\cdots \\
\cdots\end{array}$ & $\begin{array}{l}\cdots \\
\cdots \\
\cdots \\
\cdots \\
\cdots \\
\cdots\end{array}$ & $\begin{array}{l}3 \cdot 14 \\
3 \cdot 36 \\
0 \cdot 55 \\
1 \cdot 43 \\
5 \cdot 03 \\
1 \cdot 05 \\
1 \cdot 54\end{array}$ & $\begin{array}{l}1 \cdot 96 \\
2 \cdot 58 \\
1 \cdot 42 \\
1 \cdot 69 \\
4 \cdot 18 \\
1 \cdot 94\end{array}$ \\
\hline All Malformed Individua & & .. & $23 \cdot 90$ & $23 \cdot 99$ \\
\hline
\end{tabular}

The Liverpool data will be presented in detail elsewhere.

\section{SUMMARY}

The incidence of congenital malformations in Liverpool and Bootle in the 5 years 1960 to 1964 is presented in summary. Comparison is made with an earlier population survey in Birmingham. The proportion of infants malformed is similar but the incidence of neural tube defects is higher in Liverpool.

It is a pleasure to acknowledge the help and cooperation received from Prof. J. D. Hay and Prof. A. B. Semple; paediatric registrars and district midwives; and my past and present research assistants, particularly Mrs Eileen Macallister. I am indebted to Dr Ian Leck for his helpful comments.

\section{REFERENCES}

Leck, I. (1966). Lancet, $2,791$.

McKeown, T., and Record, R. G. (1960). "Ciba Foundation Symposium on Congenital Malformations", ed. G. E. W. Wolstenholme and C. M. O'Connor, p.2. Churchill, London.

Smithells, R. W. (1962). Develop. Med. Child Neurol., 4, 320. 